\title{
Phytochemical Screenings and Bioactivities of Duabanga grandiflora (Roxb. ex DC.) Walp.
}

\author{
Farjana Akhter', Quazi Sufia Islam², Mohiminul Adib², Abdullah Al Faruq ${ }^{1}$ \\ and Mohammed Ibrahim ${ }^{1}$
}

${ }^{1}$ Department of Pharmacy, Southern University of Bangladesh, Mehedibag, Chittagong, Bangladesh

${ }^{2}$ Department of Pharmaceutical Chemistry, Faculty of Pharmacy, University of Dhaka

Dhaka-1000, Bangladesh

(Received: October 5, 2018; Accepted: November 20, 2018; Published: January 17, 2019)

\begin{abstract}
The aim of this research was to find out the phytochemical constituents and to evaluate the antibacterial, antioxidant, antidiarrheal and antipyretic activities of different extracts of Duabanga grandiflora. Antibacterial study was carried out by the disk diffusion method where the $n$-hexane extract showed the inhibitory activity against Staphylococcus aureus $(12.3 \mathrm{~mm})$ and Bacillus cereus $(11.3 \mathrm{~mm})$ as compared to standard drug ciprofloxacin. A quantitative antioxidant assay was done by DPPH free radical scavenging activity, where at the dose of $100 \mu \mathrm{g} / \mathrm{ml}$ the different extracts of $D$. grandiflora leaves revealed the highest inhibition of $81.07,82.48$, and $80.33 \%$, respectively in comparison to standard ascorbic acid $(86.9 \%)$. The ethanol extract showed $\mathrm{IC}_{50}$ value $1.91 \mu \mathrm{g} / \mathrm{ml}$, which was found to be as potent as standard ascorbic acid $(1.90 \mu \mathrm{g} / \mathrm{ml})$. In antidiarrheal activity test by using castor oil induced diarrheal mice, the result showed different extracts $(500 \mu \mathrm{g} / \mathrm{ml})$ of plant possessed moderate antidiarrheal activity. It significantly increased the latency period and reduced the number fecal count in comparison to standard drug loperamide $3 \mathrm{mg} / \mathrm{kg}$ body weight. In antipyretic activity test by using Brewer's yeast induced pyrexia in Swiss albino mice the different extracts of $D$. grandiflora demonstrated mild to moderate antipyretic activity as compared to standard paracetamol.
\end{abstract}

Key words Duabanga grandiflora, antimicrobial, antioxidant, antipyretic, antidiarrheal.

\section{Introduction}

Many therapeutic agents used to alleviate various diseases in human has been isolated and then developed from natural sources, especially of plant origin. Hence, plants will always remain one of the main focuses for the discovery and development of antibiotics, anti-cancer, antioxidant, antipyretic agents and other bio-molecules serving as a potential treatment (Gurib-Fakim, 2006).

The plant Duabanga grandiflora belongs to family Lythraceae, a moderate-sized family of angiosperms among which most genera are woody shrubs or small trees (Hooker, Fitch and Cathcart, 1855); the plant is a large evergreen plant (Bengali:
Duyabanga) and it is being used traditionally to treat skin diseases such as eczema or atopic dermatitis (Santiago et al., 2015). D. grandiflora is instinctive to Nepal, Southeast Asia, Eastern India, Laos, Cambodia, Malaysia, Myanmar, Thailand, Vietnam and most importantly in the forest and hill tracks of Bangladesh (National Parks, 2018). Compounds such as, 5-formylfurfuryl esters, duabanganals A-D, together with sixteen known compounds, a known 5formylfurfuryl ester, latifolinal, eight pentacyclic triterpenes, a benzofuran derivative, an ellagic acid derivative, vanillin, $\beta$-sitosterol, $\beta$-sitosterol glucoside, 3-hydroxy-4-methoxycinnamaldehyde, and 5-formylfurfurol were isolated from the stem

Correspondence to: Mohammed Ibrahim; Email: mdibrahim_sub@yahoo.com; Mobile number: +880162240-1098. 
bark of D. grandiflora where several of these metabolites were evaluated for cytotoxic activities against six cancer cell lines (Kaweetripob et al., 2012). In another study, it has been found that the leaf extract of $D$. grandiflora actively affected several human skin cells such as skin whitening, antiaging, and anti-inflammation (Tsukiyama et al., 2010).

As parts of continuing studies with medicinal plants of Bangladesh, we investigated the antibacterial, antioxidant, antidiarrheal and antipyretic activities of $D$. grandiflora growing in Bangladesh, and here in, report the results of our preliminary investigation.

\section{Materials and Methods}

Collection and preparation of plant materials: Fresh leaves were collected from the nursery of Institute of Forestry and Environmental Sciences, University of Chittagong, in the month of June and July of 2016 which is the period when the plant grows the most.

For hot extraction, about $180 \mathrm{~g}$ of the powdered leaf was treated with absolute ethanol ina Soxhlet apparatus (Quickfit, England). After evaporation of the solvent, a gummy concentrate was obtained which was designated as the hot ethanolic crude extract $(5 \mathrm{~g})$. Solvent-solvent partitioning was done using the protocol design by Kupchan and modified by Van-Wagenen et al. in 1993 (Moon, 2018). The crude ethanol extract $(5 \mathrm{~g})$ was dissolved in $10 \%$ aqueous methanol and fractionated in a separatory funnel with $n$-hexane and chloroform. The obtained fractions were evaporated in a rotary evaporator rendering a concentrate of $n$-hexane, chloroform and aqueous soluble fractions, which were properly labeled and stored at $4^{\circ} \mathrm{C}$ until use.

Antibacterial activity: The extracts of $D$. grandiflora were screened for antimicrobial sensitivity against 6 human pathogenic bacteria by the disc diffusion method (Brown and Kothari, 1975). All the microbial species were collected from the Microbiology Lab of Department of Pharmacy, Southern University Bangladesh, Chittagong.
Standard discs were prepared by ciprofloxacin and the antibacterial activity of the test agent was determined by measuring the diameter of the zone of inhibition in term of mm (Aboaba and Efuwape, 2001).

Antioxidant activity: The radical scavenging potential of the test samples was determined by evaluating the antioxidant activities of the stable 1,1diphenyl-2-picrylhydrazyl (DPPH) free radical and standard ascorbic acid was used as positive control (Brand-Williams et al., 1995). The half maximal inhibitory concentration $\left(\mathrm{IC}_{50}\right)$ was determined graphically in comparison to standard ascorbic acid (Blois, 1958).

Antidiarrheal activity: The study was conducted as per the method where the Swiss albino mice were all screened initially where they were divided into control, standard and three test groups containing three mice in each group, e.g. control group receiving vehicle (1\% Tween-80) at a dose of $10 \mathrm{ml} / \mathrm{kg}$ body weight orally, the standard group receiving loperamide at the dose of $3 \mathrm{mg} / \mathrm{kg}$ body weight orally and test groups receiving the ethanol, $n$-hexane and chloroform extract of $D$. grandiflora leaves at the dose of $500 \mathrm{mg} / \mathrm{kg}$ body weight orally (Shoba and Thomas, 2001). During the observation period (4 hrs), the total latency periods (first diarrheal stool after the administration of castor oil) and the number of diarrheic feces excreted by the animals were recorded.

Antipyretic activity: The antipyretic activities of extract were evaluated using Brewer's yeast induced pyrexia in the Swiss albino mice where the animals were divided into control, standard and one test group (Adams, 1960). Before yeast injection, rectal temperature of mice was recorded and at the $24^{\text {th }} \mathrm{hrs}$ after yeast injection, the distilled water at dose of 10 $\mathrm{ml} / \mathrm{kg}$ body weight was administered orally to the control groups of animals and paracetamol at dose of $150 \mathrm{mg} / \mathrm{kg}$ was administered orally to standard group of animals and finally the different extracts of leaves of $D$. grandiflora were administered orally at a dose of $500 \mathrm{mg} / \mathrm{kg}$ of body weight. 


\section{Results and Discussion}

The preliminary phytochemical screenings revealed that the ethanol extract of $D$. grandiflora contained alkaloids, steroids, tannins, saponins, and reducing sugars, whereas the chloroform soluble material contained steroids, saponins, reducing sugars and gums. On the other hand, the $n$-hexane soluble material contained alkaloids, saponins, and steroids. Glycosides and amides were not found in any test samples.

The result obtained from the antibacterial sensitivity of the extracts of $D$. grandiflora was compared with the standard drugs viz. ciprofloxacin testing. During the anti-bacterial screening, the $n$ hexane soluble material of ethanol extract showed inhibitory activity against all tested pathogenic bacteria. Among them, it displayed the highest inhibition against $S$. aureus $(12.3 \mathrm{~mm})$ and $B$. cereus $(11.3 \mathrm{~mm})$. The ethanol extract demonstrated weak inhibition against $L$. casei $(8 \mathrm{~mm})$ and $B$. cereus $(7.8$ $\mathrm{mm}$ ) only. On the other hand, the chloroform-soluble fraction did not show any inhibition against the pathogenic bacteria (Table 1). However, the antibacterial activity of the extractives was considered less significant when compared to that of the effects of the reference standard, ciprofloxacin.

During free radical scavenging assays at the dose $100 \mu \mathrm{g} / \mathrm{ml}$, ethanol extract and its $n$-hexane, and chloroform-soluble fractions produced the significant inhibition of $81.07,82.48$, and $80.33 \%$, respectively when compared with standard ascorbic acid (86.9\%). The $\mathrm{IC}_{50}$ for ethanol extracts and its chloroform and $n$-hexane soluble material were $1.91,2.43$ and 2.15 $\mu \mathrm{g} / \mathrm{ml}$, respectively whereas that for ascorbic acid the value was $1.90 \mu \mathrm{g} / \mathrm{ml}$ (Table 2 and 3). Therefore, the ethanol extract showed potent antioxidant activity to the standard ascorbic acid.

In antidiarrheal activity test, different extractives (ethanol, chloroform, $n$-hexane) of $D$. grandiflora leaves at $500 \mathrm{mg} / \mathrm{kg}$ body weight significantly increased latency period to 60.67, 100 and 91 minute, respectively in comparison to the standard drug loperamide (161 minute) and also reduced the total number of defecation (Table 4). Thus, the $n$-hexane and chloroform-soluble fractions showed moderate antidiarrheal activity.

Table 1. Antibacterial activity of $\boldsymbol{D}$. grandiflora extractives and ciprofloxacin.

\begin{tabular}{lcccc}
\hline \multirow{2}{*}{ Test organisms } & \multicolumn{4}{c}{ Zone of inhibition in diameter (mm) } \\
\cline { 2 - 5 } & $\begin{array}{c}\text { Ethanol soluble } \\
\text { material }\end{array}$ & $\begin{array}{c}n \text { - hexane soluble } \\
\text { material }\end{array}$ & $\begin{array}{c}\text { Chloroform soluble } \\
\text { material }\end{array}$ & $\begin{array}{c}\text { Ciprofloxacin } \\
\text { (standard) }\end{array}$ \\
\hline Staphylococcus aureus & - & 12.3 & - & 27.0 \\
Bacillus cereus & 7.83 & 11.3 & - & 29.3 \\
Escherichia coli & - & 8.00 & - & 26.3 \\
Salmonella paratyphi & - & 9.3 & - & 25.6 \\
Salmonella typhi & - & 8.8 & - & 24.3 \\
Lactobacillus casei & 8.0 & 8.8 & - & 25.3 \\
\hline
\end{tabular}

Table 2. DPPH inhibitory action of different fractions of $D$. grandiflora and standard, ascorbic acid.

\begin{tabular}{ccccc}
\hline $\begin{array}{c}\text { Concentration } \\
(\mu \mathrm{g} / \mathrm{ml})\end{array}$ & $\begin{array}{c}\text { \% Inhibition by } \\
\text { ethanol extract }\end{array}$ & $\begin{array}{c}\text { \% Inhibition of } n- \\
\text { hexane soluble } \\
\text { fraction }\end{array}$ & $\begin{array}{c}\text { \% Inhibition of } \\
\text { chloroform soluble } \\
\text { fraction }\end{array}$ & $\begin{array}{c}\text { \% Inhibition by } \\
\text { ascorbic acid } \\
\text { (standard) }\end{array}$ \\
\hline 100 & 81.07 & 82.48 & 80.33 & 86.97 \\
80 & 74.77 & 73.03 & 73.36 & 73.78 \\
60 & 64.89 & 65.89 & 54.69 & 66.06 \\
40 & 47.14 & 46.47 & 42.57 & 50.46 \\
20 & 35.91 & 32.61 & 34.11 & 38.92 \\
\hline
\end{tabular}


Table 3. $\mathrm{IC}_{50}$ of different fractions of $D$. grandiflora and ascorbic acid.

\begin{tabular}{lc}
\hline Treatment groups & $\mathrm{IC}_{50}(\mu \mathrm{g} / \mathrm{ml})$ \\
\hline Ascorbic acid & 1.90 \\
Ethanol soluble material & 1.91 \\
Chloroform soluble material & 2.43 \\
$n$-hexane soluble material & 2.15 \\
\hline
\end{tabular}

Table 4. Antidiarrheal activity of D. grandiflora.

\begin{tabular}{lccc}
\hline Test groups & \% Defecation & $\begin{array}{c}\text { \% Inhibition of } \\
\text { defecation }\end{array}$ & $\begin{array}{c}\text { Total number of faeces } \\
(240 \mathrm{~min})\end{array}$ \\
\hline Control(1\% Tween-80) & 100 & 0 & $31.8 \pm 1.08$ \\
Standard (loperamide) & 40.6 & 59.4 & $12.9 \pm 1.08$ \\
Ethanol soluble material & 72.6 & 27.4 & $23.1 \pm 2.48$ \\
Chloroform soluble material & 44.3 & 55.7 & $14.1 \pm 0.41$ \\
$n$-hexane soluble material & 44.3 & 55.7 & $14.1 \pm 0.81$ \\
\hline
\end{tabular}

Table 5. Antipyretic activity of $\boldsymbol{D}$. grandiflora.

\begin{tabular}{lccccc}
\hline \multirow{2}{*}{ Treatment } & \multicolumn{5}{c}{ Rectal temperature $\left({ }^{\circ} \mathrm{F}\right)$} \\
\cline { 2 - 6 } & 0 hour & $1^{\text {st }}$ hour & $2^{\text {nd }}$ hour & $3^{\text {rd }}$ hour & $4^{\text {th }}$ hour \\
\hline Control & $100.37 \pm 0.426$ & $100.54 \pm 0.460$ & $100.47 \pm 0.497$ & $100.5 \pm 0.495$ & $100.37 \pm 0.389$ \\
(distilled water) & $100.27 \pm 0.248$ & $99.44 \pm 0.268$ & $98.47 \pm 0.108$ & $98.17 \pm 0.108$ & $98 \pm 0.142$ \\
$\begin{array}{l}\text { Standard } \\
\text { (paracetamol) }\end{array}$ & $100.37 \pm 0.340$ & $98.5 \pm 0.050$ & $97.3 \pm 0.100$ & $97.2 \pm 0.087$ & $98.1 \pm 0.058$ \\
$\begin{array}{l}\text { Ethanol extract } \\
n \text {-hexane soluble }\end{array}$ & $99.2 \pm 0.389$ & $97.7 \pm 0.141$ & $96.3 \pm 0.0817$ & $96.3 \pm 0.227$ & $97.4 \pm 0.108$ \\
$\begin{array}{l}\text { material } \\
\begin{array}{l}\text { Chloroform } \\
\text { soluble material }\end{array}\end{array}$ & $99.8 \pm 0.108$ & $100.54 \pm 0.460$ & $100.47 \pm 0.497$ & $100.5 \pm 0.495$ & $98.1 \pm 0.058$ \\
\hline
\end{tabular}

The test for antipyretic activity revealed that the ethanol extract reduced the pyresis in mice from $100.2^{\circ} \mathrm{F}$ to $98.1^{\circ} \mathrm{F}$ in $\left(1^{\text {st }}\right.$ to $\left.4^{\text {th }} \mathrm{hrs}\right)$ whereas the $n$ hexane and the chloroform soluble fractionate reduced the temperature from $99.2^{\circ} \mathrm{F}$ to $98.5^{\circ} \mathrm{F}$ and from $99.8^{\circ} \mathrm{F}$ to $98.5^{\circ} \mathrm{F}$, respectively in $1^{\text {st }}$ to $4^{\text {th }}$ hour (Table 5). Therefore, it was evident that different extracts of $D$. grandiflora possess mild to moderate antipyretic activity.

\section{References}

Aboaba, O.O. and Efuwape, B.M. 2001. Antibacterial properties of some Nigerian species. Bio. Res. Comm. 13, 183-188.
Adams, S.S. 1960. Analgesic and antipyretics. J. Pharm.Pharmacol. 12, 251-252.

Blois, M.S. 1958. Antioxidant determinations by the use of a stable free radical. Nature, 181, 1199.

Brand-Williams, W., Cuvelier, M.E. and Berset, C.L.W.T. 1995. Use of a free radical method to evaluate antioxidant activity. LWT-Food Sci. Techno. 28, 2530.

Brown, D.F. and Kothari, D. 1975. Comparison of antibiotic discs from different sources. J. Clin. Pathology, 28, 779-783.

Gurib-Fakim, A. 2006. Medicinal plants: traditions of yesterday and drugs oftomorrow. Molecular aspects of Medicine. 27, 1-93. 
Hooker, J.D., Cathcart, J.F. and Fitch, W.H. 1855. Illustrations of Himalayan plants.Lovell Reeve: London. 1-3.

Kaweetripob, W., Mahidol, C., Prachyawarakorn, V., Prawat, H. and Ruchirawat, S. 2012. 5-Formylfurfuryl esters from Duabanga grandiflora. Phytochemistry, 76, 78-82.

Moon, R. 2018. Kupchan Method of Partitioning | Solvent | Solubility. [Online] Available at: https://www. scribd. com/doc/187920818/Kupchan-Method-of-Partitioning [Accessed 16 December 2018].

National Parks. 2013. Flora Fauna Web - Plant Detail Duabanga grandiflora. [Online] Available at: https://florafaunaweb.nparks.gov.sg/special-pages/ plant-detail.aspx?id=2864 [Accessed 16 December 2018].
Santiago, C., Lim, K.H., Loh, H.S. and Ting, K.N. 2015. Inhibitory effect of Duabanga grandiflora on MRSA biofilm formation via prevention of cell-surface attachment and PBP2a production. Molecules, 20, 4473-4482.

Shoba, F.G. and Thomas, M. 2001. Study of antidiarrhoeal activity of four medicinal plants in castor-oil induced diarrhoea. J. Ethnopharmacology, 76, 73-76.

Thamaraiselvi, P. and Jayanthi, P. 2012. Preliminary studies on phytochemicals and antimicrobial activity of solvent extracts of Eichhorniacrassipes (Mart.) Solms. Asian J. Plant Sci. Res. 2, 115-122.

Tsukiyama, M., Sugita, T., Kikuchi, H., Yasuda, Y., Arashima, M., Okumura, H., Lhieochaiphant, S. and Shoyama, Y. 2010. Effect of Duabanga grandiflora for human skin cells. The American J. Chinese Medi. 38, 387-399. 